\title{
Determination of Acidic Dissociation Constants of Chlorthalidone and Terbutaline in Water Using DFT and Ab Initio Methods
}

\author{
DFT ve Başlangıç Yöntemlerini Kullanılarak Klortalidon ve \\ Terbütalinin Asidik Ayrışma Sabitlerinin Belirlenmesi
}

\author{
Research Article
}

Farhoush Kiani ${ }^{*}$ and Ali Rajabalinezhad ${ }^{2}$

'Department of Chemistry, Faculty of Science, Ayatollah Amoli Branch, Islamic Azad University, Amol, Iran. ${ }^{2}$ Department of NanoChemical Engineering, Faculty of Nanotechnology, Semnan University, Semnan, Iran.

\begin{abstract}
A B S TR ACT
$\mathrm{n}$ the present study, $\mathrm{pK}_{\mathrm{a}}$ values of both drug called Chlorthalidone and Terbutaline were determined in aqueous solution. For this purpose, the B3LYP calculation with the $6-31+G(d)$ basis set was utilized. The reactions and equilibria that possess a high hydrogen-band-donor capability and constitute the indispensable theoretical basis to calculate the acidity constants of Chlorthalidone and Terbutaline, are shown. To analyze the formation of intermolecular hydrogen bonds between the existent species and water molecules, Tomasi's method was used. In this way, it was determined that in alkaline aqueous solutions the cation, anion, and neutral species of Chlorthalidone and Terbutaline are solvated with one, two, three, and four molecules of water, respectively. To proceed, the calculated $\mathrm{pK}_{\mathrm{a}}$ were compared with the experimental values, which there is comparable agreement between them. The resulting data illustrated that the method was likely to be useful for the prediction of pKa values in aqueous solution.
\end{abstract}

\section{Key Words}

chlorthalidone, terbutaline, acidic dissociation constant, intermolecular hydrogen bond.

\section{Ö z}

U çalışmada klortalidon ve terbütalin ilaçlarının pK $\mathrm{K}_{\mathrm{a}}$ değerleri sulu çözeltileri içinde hesaplanmıştır. B3LYP hesaplamaları ile 6-31+G(d) temel setinden faydalanmak amaçlanmıştır. Hidrojen bağı verici özelliği yüksek olan ve aynı zamanda klortalidon ve terbütalin için asitlik sabitlerinin hesaplanmasında teorik açıdan vazgeçilmez olan denge ve tepkimeler gösterilmiştir. Var olan türler ve su molekülleri arasındaki hidrojen bağı oluşumlarını analiz etmek için Tomasi yöntemi kullanıImıştır. Böylece klortalidon ve terbütalinin alkali su çözeltisi içerisindeki katyon, anyon ve nötr oluşumlarının, sırasıyla bir, iki, üç ve dört su molekülüyle çözünebildiği saptanmıştır. Sonraki adımda hesaplanan $\mathrm{pK}_{a}$ değerleri deneysel sonuçlarla karşılaştırılmış ve kabul edilebilir bir örtüşme görülmüştür. Elde edilen veriler uygulanan tekniğin sulu çözeltilerde $\mathrm{pK}_{\mathrm{a}}$ tahminlerinde kullanışlı bir seçenek olacağını göstermektedir.

\section{Anahtar Kelimeler}

klortalidon, terbütalin, asidik ayrılma sabiti, moleküllerarası hidrojen bağı.

Article History: Received: Oct 10, 2015; Revised: Dec 12, 2016; Accepted: Dec 10, 2017; Available Online: Feb 20, 2018.

DOI: $10.15671 /$ HJBC.2018.210

Correspondence to: F. Kiani; Department of Chemistry, Faculty of Science, Islamic Azad University, Amol, Iran. 


\section{INTRODUCTION}

The ability to deliver therapeutic agents to a sick in a pulsatile or staggered release profile has been a major target in drug delivery research over the last two decades. In ancient pharmacy system, due to non-real prescription of drug dose, high amount of drug consume without any profit in cardiovascular system and mean tissues till reach to point of effect and may be cause for side effects during its path. The technology can allow target delivery of drugs to different areas of the body. Therefore, drug delivery technology (DDT) is increasingly important as a component of drug development. A key issue in drug delivery system is to maximize the drug access to specific sites, and to be able to control the release of drugs, in order to maintain a desired drug concentration level for long periods of time without reaching a toxic level or dropping below the minimum effective level [1].

Using nanotechnology, it may be possible to achieve (1) improved delivery of poorly watersoluble drugs; (2) targeted delivery of drugs in a cell- or tissue specific manner; (3) transcytosis of drugs across tight epithelial and endothelial barriers; (4) delivery of large macromolecule drugs to intracellular sites of action; (5) co-delivery of two or more drugs or therapeutic modality for combination therapy; (6) visualization of sites of drug delivery by combining therapeutic agents with imaging modalities; and (7) real-time read on the in vivo efficacy of a therapeutic agent [2].

Diuretics are a wonderful group of compounds. There are several classes of diuretics, but all diuretics enhance the excretion of water from bodies [3]. Thiazides are a type of diuretics often used to treat hypertension and edema that these thiazides were developed during the 1950s. Although they lower blood pressure effectively, the mechanisms have confused researchers [4]. Hypertension causes devastating action all over the time. Hypertension increases to the workload of the heart and arteries. It can mar the blood vessels of the brain, heart, and kidneys. Therefore is used from Chlorthalidone (CTD) to treat hypertension [5]. Although CTD does not have a thiazidic construction, it presents the same effects of the thiazidic diuretics. It reduces the amount of water in the body by raising the flow of urine, which helps to lower arterial pressure [6]. Relievers are medicines which are specifically designed to relieve asthma symptoms by relaxing the muscle cells that surround the airways. This allows the airways to open so that air can pass more easily in and out of the lungs. Nowadays reliever medications come in two types: shortacting and long-acting. Terbutaline is in the class of Short-acting reliever medications which it can be specifically used to treat asthma symptoms. Terbutaline works as bronchodilators. In severe asthma, bronchodilators are usually given intravenously or by inhalation [7-9].

Many drug compounds include at least one acidic and/or basic functionality, and the ionization state of these groups play a large role in determining the physiochemical properties of a compound. The pKa for a compound creates a means of specifying the extent of ionization of the compound at any solution $\mathrm{pH}$. Information of a compound's pKa value plays a main role in the expansion of drug delivery formulations $[10,11]$.

Aqueous pKa values are especially useful due to their environmental and pharmacological applications, because it governs solubility, absorption, distribution, metabolism and elimination $[12,13]$. In recent years a number of methods employed for pKa measurements based on solubility [14], potentiometric titration [15], spectrophotometry [16], HPLC [17] and, most recently, on capillary electrophoresis (CE) [18] and Liquid chromatography (LC) [19]. On the other hand, the theoretical prediction of pKa values using quantum chemical methods has attracted a great extent of interest. So now, pKa values can be predicted by computational methods on the basis of molecular structure, applying various quantum theoretical techniques. The pKa can be calculated from the energy of the following reaction:

$$
\mathrm{AH} \stackrel{\ddot{A} \mathrm{G}}{\longleftrightarrow} \mathrm{A}+\mathrm{H}
$$

Using the relation:

$\mathrm{pK}_{\mathrm{a}}=\Delta \mathrm{G} / 2 \cdot 303 R T$

$\Delta G$ is the free energy of reaction obtained by taking the difference of the molecular free energies of the products from the reactant [2024]. 


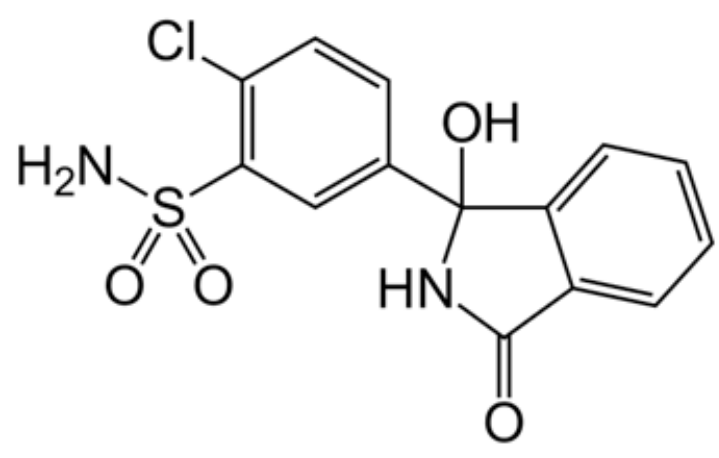

(a)

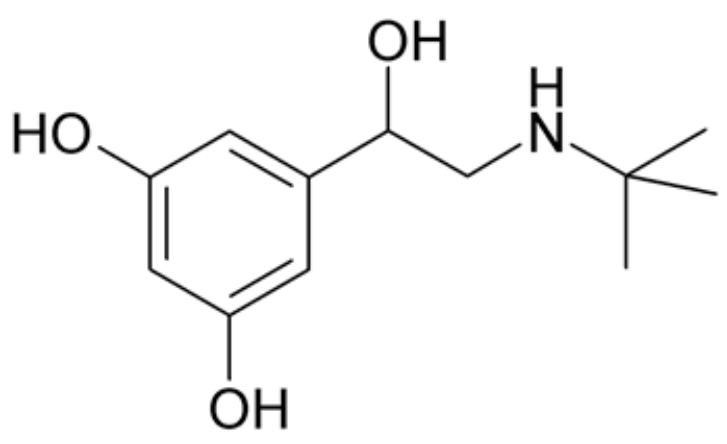

(b)

Figure 1. The structures of the (a) Chlorthalidone and (b) Terbutaline for carrying out the calculations.

Polarizable continuum models (PCM) by Tomasi and coworkers have been applied to compute free energy differences for cations, neutral compounds, and their anions. It is one of the most used and reliable continuum solvation methods [25]. On the basis of solvation free energies, the pKa values were obtained for the compounds in question by using thermodynamic equations, involving the combined experimental and computed data [26].

The increasing popularity of quantum mechanical (QM) methods for the calculation of drug design is due to the first principle nature of QM, which should provide the highest accuracy. It is an understatement to say that the density functional theory (DFT) has strongly influenced the evolution of quantum chemistry during the past 15 years; the term "revolutionalized" is perhaps more appropriate. Based on the famous Hohenberg and Kohn theorems [27], DFT provided a sound basis for the development of computational strategies for obtaining information about the energetics, structure, and properties of (atoms and) molecules at much lower costs than traditional ab initio wave function techniques. In DFT methods, Becke's three parameters exchange functional (B3) $[28,29]$ incorporated with gradient-corrected correlation functional of Lee, Yang and Parr (LYP) [30] by implementing the split-valence polarized $6-31+G(d)$ basis set $[31,32]$ have been used for the calculation of molecular structure optimization.

This article refers to the influence of factors such as the Self-Consistent Reaction Field
(SCRF) model applied, choice of a particular thermodynamic equation, atomic radii used to build a cavity in the solvent (water), optimization of geometry in water, inclusion of electron correlation, and the dimension of the basis set on the solvation free energies and on the calculated $\mathrm{pK}_{\mathrm{a}}$ values. In this study, pKa values of Chlorthalidone and Terbutaline were specified in aqueous solution by an ab initio method and at a temperature of $25^{\circ} \mathrm{C}$. To explain the acidic dissociation constants obtained, we investigated the molecular conformations and solute-solvent interactions of the cation, anion, and neutral species of Chlorthalidone and Terbutaline using $a b$ initio and density functional theory (DFT) methods.

\section{Computational Methods}

All the theoretical computations were performed using CS Chem3D version 5.0 and Gaussian 98 program package $[33,34]$. The initial geometry and different conformers of Chlorthalidone and Terbutaline (see Figure 1) were built with the help of the mentioned softwares by the semi empirical PM3 method. All the initial geometries and solvated molecules in water were optimized with the Gaussian 98 program packages using the B3LYP/6-31+G(d) methods and the default convergence criteria. The polarized continuum model (PCM) which is the ideal conceptual framework to describe solvent effects on all species involved in the selected ionization reaction, was used [35]. Furthermore, to shed light on the experimental pKa values of these drugs in water, several conformers were tested by the excel program, but some of the conformers were 
Table 1. Calculated Total Energy Using the Tomasi method at the B3LYP/6-31+G(d) Level of Theory for Cationic, Neutral, and Anionic Species of Chlorthalidone and Terbutaline, at $298.15 \mathrm{~K}^{\mathrm{a}}$.

\begin{tabular}{|c|c|c|c|c|c|c|}
\hline & & $G_{0}$ sol & Gosol/molecule & & $G_{0}$ sol & $G_{0}$ sol/molecule \\
\hline $\mathbf{N}$ & $\begin{array}{l}\text { solvated } \\
\text { species }\end{array}$ & (Hartree) & $\left(\right.$ kj. $\left.\mathrm{mol}^{-1}\right)$ & $\begin{array}{c}\text { solvated } \\
\text { species }\end{array}$ & (Hartree) & \\
\hline \multicolumn{4}{|c|}{ Terbutaline } & \multicolumn{3}{|c|}{ Chlorthalidone } \\
\hline 0 & $\mathrm{H}_{3} \mathrm{~L}^{+}$ & -1968207.194 & -749.650498 & $\mathrm{H}_{2} \mathrm{~L}_{2}^{+}$ & -4751467.721 & -1809.738403 \\
\hline 1 & $\mathrm{H}_{3} \mathrm{~L}^{+}$ & -1084452.038 & -826.0919 & $\mathrm{H}_{2} \mathrm{~L}_{2}^{+}$ & -2476091.022 & -1886.186448 \\
\hline 2 & $\mathrm{H}_{3} \mathrm{~L}^{+}$ & -789866.9489 & -902.53326 & $\mathrm{H}_{2} \mathrm{~L}_{2}^{+}$ & -1717630.22 & -1962.632319 \\
\hline 3 & $\mathrm{H}_{3} \mathrm{~L}^{+}$ & -642574.2365 & -978.974364 & $\mathrm{H}_{2} \mathrm{~L}_{2}^{+}$ & -1338398.294 & -2039.075868 \\
\hline 4 & $\mathrm{H}_{3} \mathrm{~L}^{+}$ & -554199.8598 & -1055.41785 & $\mathrm{H}_{2} \mathrm{~L}_{2}^{+}$ & -1110858.844 & -2115.518855 \\
\hline 0 & $\mathrm{H}_{2} \mathrm{~L}$ & -1966966.495 & -749.177941 & $\mathrm{HL}^{+}$ & -4750391.962 & -1809.328668 \\
\hline 1 & $\mathrm{H}_{2} \mathrm{~L}$ & -1083830.825 & -825.618685 & $\mathrm{HL}^{+}$ & -2475542.398 & -1885.768528 \\
\hline 2 & $\mathrm{H}_{2} \mathrm{~L}$ & -789452.666 & -902.059884 & $\mathrm{HL}^{+}$ & -1717261.775 & -1962.211319 \\
\hline 3 & $\mathrm{H}_{2} \mathrm{~L}$ & -642270.5384 & -978.511674 & $\mathrm{HL}^{+}$ & -1338127.711 & -2038.663629 \\
\hline 4 & $\mathrm{H}_{2} \mathrm{~L}$ & -553956.9623 & -1054.955276 & $\mathrm{HL}^{+}$ & -1110638.577 & -2115.099379 \\
\hline 0 & $\mathrm{HL}^{-}$ & -1965727.829 & -748.706158 & $\mathrm{~L}$ & -4749309.665 & -1808.916443 \\
\hline 1 & $\mathrm{HL}^{-}$ & -1083222.626 & -825.155384 & $\mathrm{~L}$ & -2475001.995 & -1885.356871 \\
\hline 2 & $\mathrm{HL}^{-}$ & -789052.2712 & -901.602377 & 2 & -1716898.167 & -1961.795847 \\
\hline 3 & $\mathrm{HL}^{-}$ & -641961.374 & -978.040656 & $\mathrm{~L}$ & -1337856.169 & -2038.24993 \\
\hline 4 & $\mathrm{HL}^{-}$ & -553711.9538 & -1054.488682 & 4 & -1110423.029 & -2114.688888 \\
\hline 0 & $\mathrm{~L}_{2}^{-}$ & -1964472.16 & -748.227899 & & Water [26] & \\
\hline 1 & $\mathrm{~L}_{2}$ & -1082592.883 & -824.675671 & $\mathrm{H}_{3} \mathrm{O}^{+}$ & $-2.0180 \cdot 105$ & $-7.6862 \cdot 101$ \\
\hline 2 & $\mathrm{~L}_{2}^{-}$ & -788633.1749 & -901.123501 & $\mathrm{H}_{3} \mathrm{O}^{+}\left(\mathrm{H}_{2} \mathrm{O}\right)$ & $-2.0124 \cdot 105$ & $-1.5330 \cdot 102$ \\
\hline 3 & $\mathrm{~L}_{2}^{-}$ & -641649.1213 & -977.564933 & $\mathrm{H}_{3} \mathrm{O}^{+}\left(\mathrm{H}_{2} \mathrm{O}\right)_{2}$ & $-2.0105 \cdot 105$ & $-2.2973 \cdot 102$ \\
\hline \multirow[t]{7}{*}{4} & $\mathrm{~L}_{2}$ & -553461.3892 & -1054.011507 & $\mathrm{H}_{2} \mathrm{O}$ & $-2.0068 \cdot 105$ & $-7.6434 \cdot 101$ \\
\hline & & & & $\left(\mathrm{H}_{2} \mathrm{O}\right)_{2}$ & $-2.0068 \cdot 105$ & $-1.5287 \cdot 102$ \\
\hline & & & & $\mathrm{OH}^{-}$ & $-1.9941 \cdot 105$ & $-7.5952 \cdot 101$ \\
\hline & & & & $\mathrm{OH}^{-}\left(\mathrm{H}_{2} \mathrm{O}\right)$ & $-2.0006 \cdot 105$ & $-1.5240 \cdot 102$ \\
\hline & & & & $\mathrm{OH}^{-}\left(\mathrm{H}_{2} \mathrm{O}\right)_{2}$ & $-2.0028 \cdot 105$ & $-2.2885 \cdot 102$ \\
\hline & & & & $\mathrm{OH}^{-}\left(\mathrm{H}_{2} \mathrm{O}\right)_{3}$ & $-2.0039 \cdot 105$ & $-3.0529 \cdot 102$ \\
\hline & & & & $\mathrm{OH}^{-}\left(\mathrm{H}_{2} \mathrm{O}\right)_{4}$ & $-2.0044 \cdot 105$ & $-3.8173 \cdot 102$ \\
\hline
\end{tabular}

aN: total number of solvation water molecules; Gsolo, total free energy in solution; Gsolo/molecule, total energy of solvated species per water molecule; $\mathrm{H}_{2} \mathrm{~L}_{2}{ }^{+}$and $\mathrm{H}_{3} \mathrm{~L}^{+}$and $\mathrm{H}_{\mathrm{L}}{ }^{+}$, cation species; $\mathrm{L}$ and $\mathrm{H}_{2} \mathrm{~L}$, neutral; $\mathrm{HL}^{-}$and $\mathrm{L}_{2}$; anion species. 
not considered further because the estimated error in its acidic dissociation constants was unacceptable. Finally, we selected the solvation of the species by means of intermolecular hydrogen bonds (IHBs) that involve one molecule of the mentioned species and some molecules of water (see Table 1).

\section{RESULT and DISCUSSION}

Fully protonated Chlorthalidone and Terbutaline have two acid groups and three acid groups, respectively. For Chlorthalidone, a proton can be lost from either of the two groups to give different ionized species: the loss of a proton from the first ammonium group $\left(\mathrm{NH}_{3}{ }^{+}\right)$is most probable and from the second ammonium group $\left(\mathrm{NH}_{2}{ }^{+}\right)$least probable. Therefore, this concept of microscopic ionization constants $k_{1}$ and $k_{2}$ may be used, where $k_{1}$ involving the first ammonium group proton is [36]:

$\mathrm{k}_{1}=\left[\mathrm{H}^{+}\right]\left[\mathrm{C}_{14} \mathrm{H}_{8} \mathrm{CINH}_{2} \mathrm{NH}_{2}{ }^{+} \mathrm{O}_{4} \mathrm{~S}\right] /\left[\mathrm{C}_{14} \mathrm{H}_{8} \mathrm{ClNH}_{3}{ }^{+} \mathrm{NH}_{2} \mathrm{O}_{4} \mathrm{~S}\right]$

And $k_{2}$ involving the second ammonium proton $\left(\mathrm{NH}_{2}^{+}\right)$is:

It can be displayed that for a dibasic acid (Chlorthalidone) the first ionization constant $\mathrm{K}_{1}$ is

$\mathrm{K}_{2}=\left[\mathrm{H}^{+}\right]\left[\mathrm{C}_{14} \mathrm{H}_{8} \mathrm{ClNH}_{3}{ }^{+} \mathrm{NHO}_{4} \mathrm{~S} /\left[\mathrm{C}_{14} \mathrm{H}_{8} \mathrm{ClNH}_{3}{ }^{+} \mathrm{NH}_{2}{ }^{+} \mathrm{O}_{4} \mathrm{~S}\right]\right.$

the sum $k_{1}+k_{2}$ and the second ionization constant $\mathrm{K}_{2}$ is $\left(\mathrm{k}_{12} \cdot \mathrm{k}_{21}\right) /\left(\mathrm{k}_{12}+\mathrm{k}_{21}\right)$, where the subscript 12 specifies loss of proton 2 following loss of proton 1 and subscript 21 denotes loss of proton 1 following loss of proton 2 .

In the case of Terbutaline, eight differently protonated microspecies exist in solution and 12 microconstants are necessary to describe the system (Figure 2) [37].

Based on an earlier work by Taka'cs-Nova'k et al., it is proposed a three-step protonation scheme which is shown in Figure 3 with all free protons omitted for clarity [38].

It must be noted that the chemical interpretation of the changes can be determined by NMR spectroscopy exactly [39-41].

Considering the microconstants of two drugs, various reactions including cationic, zwitterion and anionic species were checked, but some of the reactions were not considered further because the estimated error in its dissociation constants was unacceptable. In the long run, the models selected for the considered system and the computed values of the dissociation constants for Chlorthalidone and Terbutaline are listed in Table 2.

The acidic dissociation constants of Chlorthalidone and Terbutaline have been determined using the CE method [42]. In the case of Terbutaline, UV spectroscopy is less suitable for the demonstration of partitioning of the neutral form because here the uncharged species has the same spectrum as that of the cation form. of course, potentiometry and spectroscopic methods are highly sensitive and as such are suitable for studying chemical equilibria solutions.

\section{Solvent-Solute Interactions: Ionic Product of Water}

For an ionization reaction in pure water or an aqueous solution, in which a water molecule, loses the nucleus of one of its hydrogen atoms to become a hydroxide ion $\left(\mathrm{OH}^{-}\right)$. The hydrogen nucleus $\left(\mathrm{H}^{+}\right)$protonates other water molecules to form hydronium $\left(\mathrm{H}_{3} \mathrm{O}^{+}\right)$, immediately.

$2 \mathrm{H}_{2} \mathrm{O} \leftrightarrow \mathrm{H}_{3} \mathrm{O}^{+}+\mathrm{OH}^{-}$

Applying law of mass action at equilibrium, the value of dissociation constant $(K)$ can be expressed as follows:

$\mathrm{K}=\left[\mathrm{H}_{3} \mathrm{O}^{+}\right]\left[\mathrm{OH}^{-}\right] /\left[\mathrm{H}_{2} \mathrm{O}\right]^{2}$

Since dissociation takes place to a very small extent, the concentration of undissociated water molecules $\left(\left[\mathrm{H}_{2} \mathrm{O}\right]\right)$; can be regarded as constant.

$\mathrm{K}_{\mathrm{w}}=\left[\mathrm{H}_{3} \mathrm{O}^{+}\right]\left[\mathrm{OH}^{-}\right]$

$\mathrm{K}_{\mathrm{w}}$ is a constant at a given temperature and is known as ionic product of water. Equations 5 and 7 are frequently used in studies of acid-base equilibria in aqueous media [43]. It must be noted 


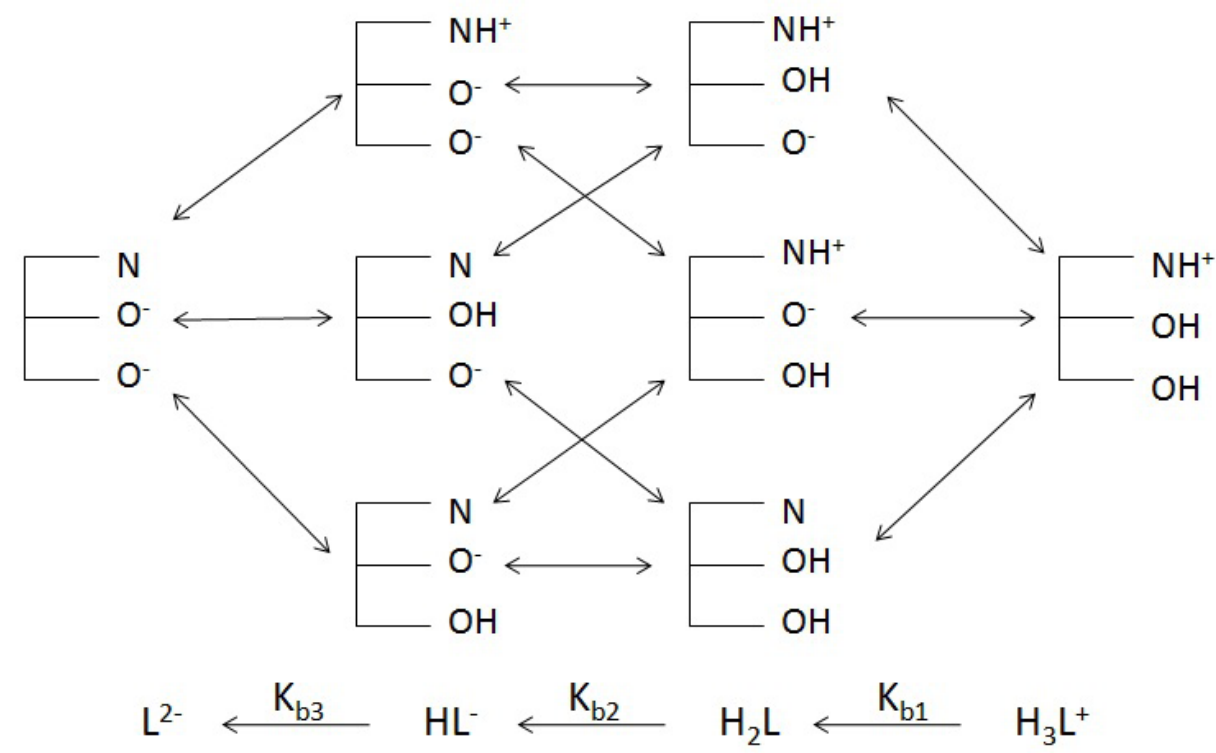

Figure 2. Protonation of Terbutaline.<smiles>CC(C)(C)[NH2+]CC(O)c1cc(O)cc(O)c1</smiles>
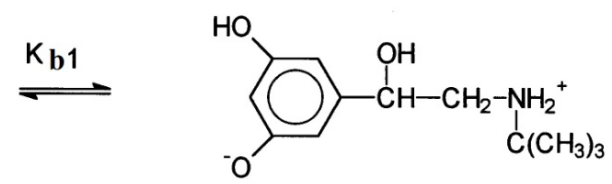

\section{$\mathrm{K}$ b2}<smiles>CC(C)(C)NCC(O)c1cc(O)cc(O)c1</smiles>

$\mathrm{K}_{\mathrm{b} 3}$

Figure 3. Suggested protonation scheme of Terbutaline.

that the solvation of anions is effective in protic solvents where hydrogen bonds can be formed between the proton of the solvent and the lone pairs of electrons of the anion. The total energies of the single and solvated $\mathrm{OH}^{-}$ion have been computed in water at the B3LYP/6-31+G(d) level of theory, using Tomasi's model. Considering the structures of the hydroxyl ion solvated with one water and also two water molecules together, it can be concluded that the IHBs between the $\mathrm{OH}$ ion and the water molecules of solvation belong to the class of moderate or strong $\mathrm{H}$ bonds. The calculated total energy values confirm $a$ in significant decrease of the total energy of the $\mathrm{OH}^{-}$ ion when its solvation increases $[44,45]$.
According to the above content and to provide a more acceptable illustration of the protolysis of water, the reaction has been shown as follows:

$3 \mathrm{H}_{2} \mathrm{O} \leftrightarrow \mathrm{H}_{3} \mathrm{O}^{+}+\mathrm{OH}^{-}\left(\mathrm{H}_{2} \mathrm{O}\right)$

The above reaction assumes that both $\mathrm{H}+$ and $\mathrm{OH}^{-}$ions are hydrated with one water molecule. Also, indicating with $\mathrm{KN} 1$ the equilibrium constant of the reaction of Equation 8 and considering the equations 5 and 7 , it is inferred that [46]:

$\mathrm{K}_{\mathrm{w}}=\mathrm{K}_{\mathrm{N} 1}\left[\mathrm{H}_{2} \mathrm{O}\right]$ 
Table 2. Values of $\mathrm{pK}_{\mathrm{a}}$ for the Protonation of Chlorthalidone and Terbutaline Obtained Using the Tomasi method at the B3LYP/6-31+G(d) Level of Theory, at $298.15 \mathrm{~K}^{\mathrm{a}}$.

Species Selected equations $\mathrm{pK}_{\mathrm{a}}$ (Calculated) $\mathrm{pK}_{\mathrm{a}}$ (Experimental) Ref Chlorthalidone $\mathrm{H}_{2} \mathrm{~L}^{+2}\left(\mathrm{H}_{2} \mathrm{O}\right)+\mathrm{H}_{2} \mathrm{O} \longleftrightarrow \mathrm{HL}^{+}\left(\mathrm{H}_{2} \mathrm{O}\right)+\mathrm{H}_{3} \mathrm{O}^{+}$ 9.26 $8.98(I=0.05)$

$$
\begin{aligned}
& \mathrm{HL}^{+}\left(\mathrm{H}_{2} \mathrm{O}\right)+2 \mathrm{H}_{2} \mathrm{O} \longleftrightarrow \mathrm{L}\left(\mathrm{H}_{2} \mathrm{O}\right)_{2}+\mathrm{H}_{3} \mathrm{O}^{+} \\
& \mathrm{H}_{3} \mathrm{~L}^{+}+2 \mathrm{H}_{2} \mathrm{O} \longleftrightarrow \mathrm{H}_{2} \mathrm{~L}\left(\mathrm{H}_{2} \mathrm{O}\right)+\mathrm{H}_{3} \mathrm{O}^{+}
\end{aligned}
$$
10.88

Terbutaline

As regards, $\left[\mathrm{H}_{2} \mathrm{O}\right]$ is the molar concentration of water; $\mathrm{K}_{\mathrm{N} 1}$ (at $298.15 \mathrm{~K}$ ) was calculated as follows:

$\mathrm{K}_{\mathrm{N} 1}=\mathrm{K}_{\mathrm{w}} /\left[\mathrm{H}_{2} \mathrm{O}\right]=1.831 \times 10^{-16}$

With a similar trend, $\mathrm{K}_{\mathrm{N} 2}$ and $\mathrm{K}_{\mathrm{N} 3}$ (at 298.15 K) were calculated as follows:

$4 \mathrm{H}_{2} \mathrm{O} \leftrightarrow \mathrm{H}_{3} \mathrm{O}^{+}+\mathrm{OH}^{-}\left(\mathrm{H}_{2} \mathrm{O}\right)_{2}$

$5 \mathrm{H}_{2} \mathrm{O} \leftrightarrow \mathrm{H}_{3} \mathrm{O}^{+}+\mathrm{OH}^{-}\left(\mathrm{H}_{2} \mathrm{O}\right)_{3}$

The selected reaction considers that $\mathrm{OH}^{-}$ions are hydrated with two water and three molecules, respectively.

$\mathrm{K}_{\mathrm{w}}=\mathrm{K}_{\mathrm{N} 2}\left[\mathrm{H}_{2} \mathrm{O}\right]^{2}$

$\mathrm{K}_{\mathrm{w}}=\mathrm{KN}_{3}\left[\mathrm{H}_{2} \mathrm{O}\right]_{3}$

As a result :

$\mathrm{K}_{\mathrm{N} 2}=\mathrm{K}_{\mathrm{w}} /\left[\mathrm{H}_{2} \mathrm{O}\right]^{2}=3.3226 \times 10^{-18}$

$\mathrm{K}_{\mathrm{N} 3}=\mathrm{K}_{\mathrm{w}} /\left[\mathrm{H}_{2} \mathrm{O}\right]_{3}=6.4149 \times 10^{-20}$

Similarly, the total energies of the single and solvated Chlorthalidone (cationic, neutral) and Terbutaline (cationic, zwitterion, and anionic) species were calculated in water at the B3LYP/6$31+G(d)$ level of the theory, using Tomasi's model. Table 1 summarizes the variations of the total energy $\left(\mathrm{kJ}^{\mathrm{mol}}{ }^{-1}\right)$ of the species per water molecule as a function of the total number of solvation water molecules. Figure 4 and Table 1 show the marked increase of the total energies of cations when the solvation increases.

The data show that the water, exerting its hydrogen-bond donor (HBD) capability, forms IHBs with the Chlorthalidone and Terbutaline species [47]. These hydrogen bonds can be classified as strong, moderate, and weak, according to their lengths, angles, and energies [45].

\section{First Ionization Constant of Chlorthalidone and Terbutaline}

It was chosen that in alkaline solutions Chlorthalidone suffers a reaction of partial neutralization as follows:

$\mathrm{H}_{2} \mathrm{~L}^{+2}\left(\mathrm{H}_{2} \mathrm{O}\right)+\mathrm{OH}^{-}\left(\mathrm{H}_{2} \mathrm{O}\right) \leftrightarrow \mathrm{HL}^{+}\left(\mathrm{H}_{2} \mathrm{O}\right)+3 \mathrm{H}_{2} \mathrm{OK}_{\mathrm{c} 1}$

$\mathrm{H}_{3} \mathrm{~L}^{+}+\mathrm{OH}^{-}\left(\mathrm{H}_{2} \mathrm{O}\right)_{3} \leftrightarrow \mathrm{H}_{2} \mathrm{~L}\left(\mathrm{H}_{2} \mathrm{O}\right)+3 \mathrm{H}_{2} \mathrm{O} \quad \mathrm{K}_{\mathrm{d} 1} \quad$ [18

In Reaction 17, $\mathrm{H}_{2} \mathrm{~L}^{+} 2\left(\mathrm{H}_{2} \mathrm{O}\right)$ is the Chlorthalidone cation (+2) solvated with one water molecule, and $\mathrm{HL}^{+}\left(\mathrm{H}_{2} \mathrm{O}\right)$ represents the cation $(+1)$ solvated with one water molecule. In Reaction $18, \mathrm{H}_{3} \mathrm{~L}^{+}$is the Terbutaline cation, and $\mathrm{H}_{2} \mathrm{~L}\left(\mathrm{H}_{2} \mathrm{O}\right)$ represents the Terbutaline zwitterion solvated with one water molecule. The earlier reaction is characterized by equilibrium constants $\left(\mathrm{K}_{\mathrm{Cl}}\right)$ and $\left(\mathrm{K}_{\mathrm{DI}}\right)$, which were theoretically obtained.

By incorporating Equations (11) and (17) and also (12) and (18), was obtained the reaction of Equations (19) and (20), which define the first ionization constant of Chlorthalidone $\left(K_{a l}\right)$ and Terbutaline $\left(\mathrm{K}_{\mathrm{b})}\right)$ : 


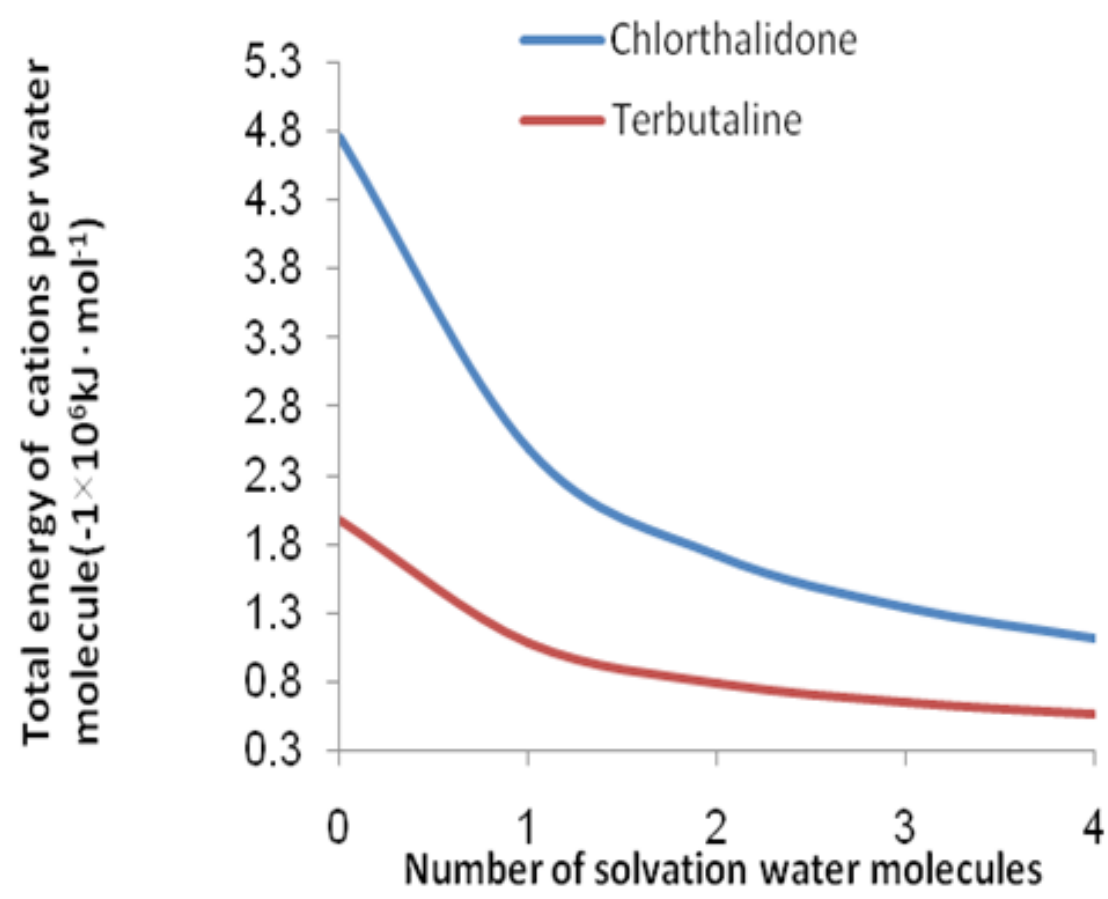

Figure 4. Plot of the total energy $\left(\mathrm{kJ} \cdot \mathrm{mol}^{-1}\right)$ of solvated Chlorthalidone and Terbutaline cations.

$\mathrm{H}_{2} \mathrm{~L}^{+} 2\left(\mathrm{H}_{2} \mathrm{O}\right)+\mathrm{H}_{2} \mathrm{O} \leftrightarrow \mathrm{HL}^{+}\left(\mathrm{H}_{2} \mathrm{O}\right)+\mathrm{H}_{3} \mathrm{O}^{+}$

$\mathrm{H}_{3} \mathrm{~L}^{+}+2 \mathrm{H}_{2} \mathrm{O} \leftrightarrow \mathrm{H}_{2} \mathrm{~L}\left(\mathrm{H}_{2} \mathrm{O}\right)+\mathrm{H}_{3} \mathrm{O}^{+}$

It is obvious that:

$\mathrm{K}_{\mathrm{al}}=\mathrm{K}_{\mathrm{C} 1} \times \mathrm{K}_{\mathrm{N} 2}$

$\mathrm{K}_{\mathrm{bl}}=\mathrm{K}_{\mathrm{D} 1} \times \mathrm{K}_{\mathrm{N} 3}$

The Previous equations were applied to determine theoretically the value of the first ionization constant of Chlorthalidone and Terbutaline in water. Table 3 and 4 summarize the optimized values of molecular properties of the $\mathrm{H}_{2} \mathrm{~L}^{+} 2\left(\mathrm{H}_{2} \mathrm{O}\right)$ cation (Figure $5 \mathrm{a}$ ), $\mathrm{OH}^{-}\left(\mathrm{H}_{2} \mathrm{O}\right)_{2}$ ion, and the $\mathrm{HL}^{+}\left(\mathrm{H}^{2} \mathrm{O}\right)$ cation (Figure 5b) for Chlorthalidone, and also the $\mathrm{H}_{3} \mathrm{~L}^{+}$cation (Figure $5 \mathrm{~d}$ ), $\mathrm{OH}^{-}\left(\mathrm{H}_{2} \mathrm{O}\right)_{3}$ ion, and the $\mathrm{H}_{2} \mathrm{~L}\left(\mathrm{H}_{2} \mathrm{O}\right)$ zwitterion (Figure $5 \mathrm{e}$ ) for Terbutaline obtained at the B3LYP/6-31+G(d) level of theory with Tomasi's method in water at 298.15 $\mathrm{K}$.

Evidently, the formation of the Chlorthalidone cation (+1) implies that the electronic density of the $\mathrm{N} 22$ atom decreases notably (in absolute value) with respect to the $\mathrm{N} 22$ atom of the Chlorthalidone cation (+2) (Table 3). Also, the formation of the Terbutaline zwitterion implies that the electronic density of the N10 atom increases notably (in absolute value) with respect to the $\mathrm{N} 10$ atom of the Terbutaline cation as shown Table 4 . It can be observed that the $p_{k 1}$ value (Chlorthalidone and Terbutaline) theoretically calculated $\left(\mathrm{pK}_{1}=\right.$ 9.26 and 8.85 ) is relatively comparable with the experimentally determined $\mathrm{pKa}\left(\mathrm{pK}_{\mathrm{a} 1}=8.98\right.$ and 8.79) [42].

\section{Second Ionization Constant of Chlorthalidone and Terbutaline}

It was chosen that the $\mathrm{HL}^{+}\left(\mathrm{H}_{2} \mathrm{O}\right)$ cation (for Chlorthalidone) and the $\mathrm{H}_{2} \mathrm{~L}$ zwitterion (for Terbutaline) suffer a total neutralization as follows:

$$
\begin{array}{ll}
\mathrm{HL}^{+}\left(\mathrm{H}_{2} \mathrm{O}\right)+\mathrm{OH}^{-}\left(\mathrm{H}_{2} \mathrm{O}\right)_{2} \leftrightarrow \mathrm{L}\left(\mathrm{H}_{2} \mathrm{O}\right)_{2}+2 \mathrm{H}_{2} \mathrm{O} & \mathrm{K}_{\mathrm{c} 2} \\
\mathrm{H}_{2} \mathrm{~L}^{+} \mathrm{OH}^{-}\left(\mathrm{H}_{2} \mathrm{O}\right)_{3} \leftrightarrow \mathrm{HL}^{-}\left(\mathrm{H}_{2} \mathrm{O}\right)+3 \mathrm{H}_{2} \mathrm{O} & \mathrm{K}_{\mathrm{c} 2}
\end{array}
$$

In this Reaction 23, $\mathrm{L}\left(\mathrm{H}_{2} \mathrm{O}\right)_{2}$ is the neutral Chlorthalidone solvated with two water molecules. 
Table 3. Calculated Structural Magnitudes Using Tomasi's method at the B3LYP/6-31+G(d) Level of Theory for the Cations, Neutral Molecule of Chlorthalidone at $298.15 \mathrm{~K}$.

species

Chlorthalidone

$\mathrm{K}_{\mathrm{C} 1}$ $\mathrm{K}_{\mathrm{C} 2}$ $\mathrm{K}_{\mathrm{al}}$ $\mathrm{K}_{\mathrm{a} 2}$ $a_{0}$ qN9 qN22 q010 q011 q012 q020 q021 q034 q035 q036 q037 $\mathrm{qH} 27$ $\mathrm{qH} 28$ $\mathrm{qH} 29$ $\mathrm{qH} 3 \mathrm{O}$ $\mathrm{qH} 33$ qH35 qH36 qH39 dH35036 dN22H36 dH33034 d021H35 dH28037

AN22H35036 AN22H33035 AN9H28037 A034H335021 AN22H33O34

\section{calculated magnitudes}

$$
\mathrm{HL}^{+}
$$

L $5.47139 \times 10+26$

\section{$2.7487 \times 10+28$}

1819784793

5.66
91422675850

5.53

$-0.881671$

$-0.350277$

$-1.033625$ $-1.002692$

$-1.235729$

$-0.452519$

$-0.662984$

$-0.462837$

$-0.726303$

$-0.64038$

$-0.655234$

$-0.612895$

$-0.536961$

$-0.414597$

$-0.690307$

$-0.76932$

$-0.519032$

$-1.100298$

$-1.081889$

$-1.055022$

.

0.560659

0.571317

0.575024

0.571452

0.562625

0.564973

0.524151

0.513411

\subsection{9}

- 0.545505

- -

0.560644

1.63926

- 1.89488

1.89488

$\begin{array}{ccc}- & - & 1.97168 \\ - & - & 1.98381 \\ - & - & 2.05303\end{array}$

176.5741

157.74426

\begin{tabular}{rr}
- & 134.23199 \\
\hline- & 141.77624 \\
\hline & 155.04642
\end{tabular}


22 | F. Kiani and A. Rajabalinezhad / Hacettepe J. Biol. \& Chem., 2018, 46 (1), 13-29

Table 3. Calculated Structural Magnitudes Using Tomasi's method at the B3LYP/6-31+G(d) Level of Theory for the Cations, Neutral Molecule of Chlorthalidone at $298.15 \mathrm{~K}^{\mathrm{a}}$ (continue).

\begin{tabular}{|c|c|c|c|}
\hline D-C4C3C2C1 & -32.052136 & -31.606238 & -32.178525 \\
\hline D-C5C4C3C2 & -0.239757 & -0.089232 & -0.181981 \\
\hline D-C6C2C1C5 & -69.202169 & -69.097333 & -64.074964 \\
\hline D-C7C6C2C1 & 29.643695 & 28.928289 & 28.239304 \\
\hline D-C8C5C4C3 & -176.253668 & -176.957027 & -176.707388 \\
\hline D-N9C8C5C4 & 178.512585 & -175.352583 & -177.842982 \\
\hline D-C10C7C6C2 & 178.579414 & -179.589697 & - \\
\hline D-011C10C7C6 & 2.339733 & -2.906465 & - \\
\hline D-C10N9C8C5 & - & - & -5.804318 \\
\hline D-011C10N9C8 & - & - & -176.288169 \\
\hline D-012C8C5C4 & 64.176803 & 71.92783 & 69.227345 \\
\hline D-C13C1C8C5 & 149.243109 & 140.682767 & 154.143681 \\
\hline D-C14C13C1C 8 & 178.424588 & 178.561283 & 177.096798 \\
\hline D-C15C14C13C1 & -0.860136 & -0.391354 & 0.290698 \\
\hline D-C16C15C14C13 & -0.758667 & -0.565803 & 0.01348 \\
\hline D-C17C1C13C14 & 1.562234 & 0.815243 & -0.644875 \\
\hline D-CL18C16C15C14 & -179.676325 & -179.565976 & 179.267007 \\
\hline D-S19C17C11C13 & 173.238183 & 177.083055 & - \\
\hline D-020S19C17C1 & -126.540082 & -120.788711 & -122.934802 \\
\hline D-021S19C17C1 & 15.942181 & 8.98578 & 7.64642 \\
\hline D-N22S19C17C1 & 124.290736 & 122.849115 & 119.724121 \\
\hline D-H23C1C13C14 & -178.236375 & - & - \\
\hline D-H24C2C1C13 & 168.844385 & - & - \\
\hline D-H23C1C17C16 & - & 178.546553 & -179.642006 \\
\hline $\mathrm{D}-\mathrm{H} 24 \mathrm{C} 2 \mathrm{C} 1 \mathrm{C} 17$ & - & 28.341488 & 20.469946 \\
\hline D-H25C3C2C1 & 148.253578 & 148.047655 & 147.303637 \\
\hline D-H26C4C3C2 & -179.641099 & 179.293498 & 178.918952 \\
\hline D-H27N6C2C1 & -150.836406 & -150.655141 & -151.549369 \\
\hline D-H28N9C8C5 & -120.810473 & -129.784592 & -176.90843 \\
\hline D-H29N9C8C5 & 119.791579 & 111.185705 & - \\
\hline D-H30012C8C5 & 15.657391 & 12.077779 & - \\
\hline D-H31C14C13C1 & 178.358033 & 179.139532 & - \\
\hline D-H32C15C14C13 & 179.615518 & 179.709326 & - \\
\hline D-H29012C8C5 & - & - & -61.203366 \\
\hline D-H30C14C13C1 & - & - & -179.685702 \\
\hline
\end{tabular}


Table 3. Calculated Structural Magnitudes Using Tomasi's method at the B3LYP/6-31+G(d) Level of Theory for the Cations, Neutral Molecule of Chlorthalidone at $298.15 \mathrm{~K}^{\mathrm{a}}$ (continue).

\begin{tabular}{cccc}
\hline D-H31C15C14C13 & - & - & 179.972921 \\
\hline H32N22S19C17 & - & - & 107.333167 \\
\hline D-H33N22S19C17 & 52.2896 & -118.787314 & -125.427425 \\
\hline D-H34N22S19C17 & -70.679558 & 113.819214 & - \\
\hline D-H35N22S19C17 & 169.97626 & - & - \\
\hline D-036N22S19C17 & 168.047124 & - & - \\
\hline D-H37036N22S19 & 143.97334 & - & - \\
\hline D-H38036N22S19 & -37.820899 & 8.348871 & 120.891683 \\
\hline D-H36035N22S19 & - & 128.319656 & 167.46884 \\
\hline D-H37035N22S19 & - & - & 112.052863 \\
\hline D-034021S19C17 & - & - & 1.572607 \\
\hline D-H35034021S19 & - & - & 126.991671 \\
\hline D-H36034021S19 & - & - & 179.277537 \\
\hline D-037011C10N9 & - & - & - \\
\hline D-H38037011C10 & - & - & - \\
\hline D-H39037011C10 & - & - & - \\
\hline
\end{tabular}

${ }^{a} K_{c 1}$ and $K_{c 2}$, equilibrium constants of equations; $K_{a 1}$ and $K_{a 2}$ first and second acidic dissociation constants of species in water; $D$, dihedral angle between the indicated atoms $(\AA)$; $a_{0}$, bohr radius $(\AA)$; q, total atomic charge (Muliken) (au); r, bond lengths between the indicated atoms; $d$, distance of the IHB between the indicated atoms $(\AA) ; A, H$-bond angles $\left(^{\circ}\right)$.
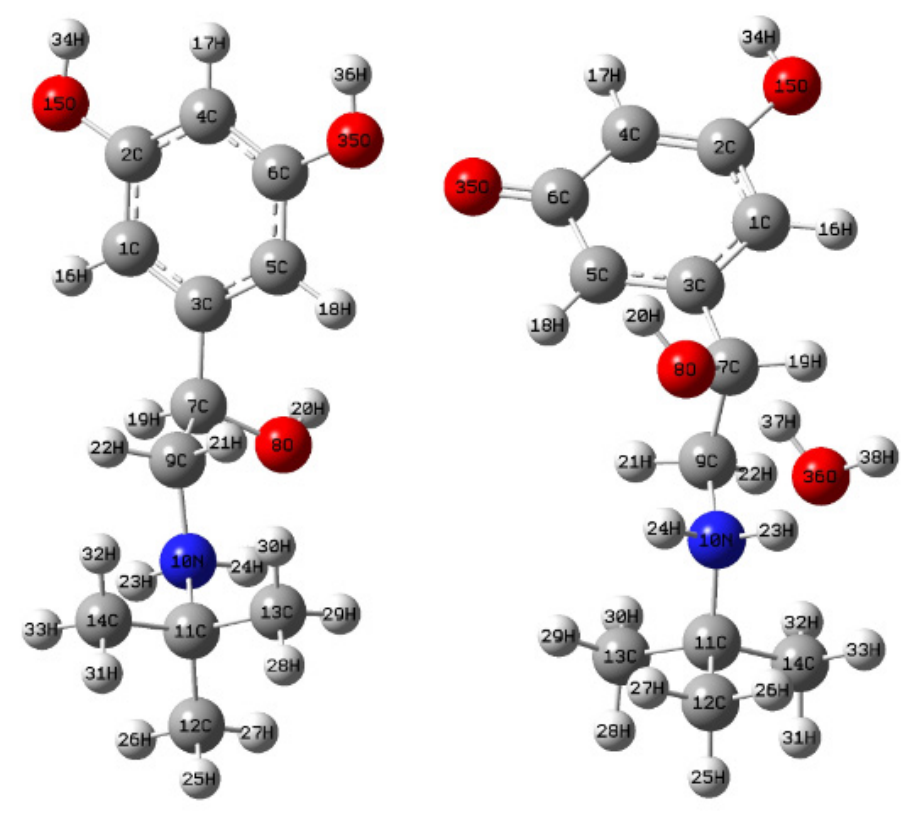

Figure 5. Calculated structure for the Chlorthalidone cations (a) and (b), natural Chlorthalidone (c), Terbutaline cation (d), and Terbutaline zwitterion (e), at the B3LYP/6-31+G(d) level of theory and using Tomasi's method in water at 298.15 K. 
Also, in reaction 24, $\mathrm{HL}^{-}\left(\mathrm{H}_{2} \mathrm{O}\right)$ represents the Terbutaline anion solvated with one water molecule. By incorporating Equations (11) and (23) as well as (12) and (24), were obtained the reaction of Equations (25) and (26):

$$
\begin{array}{ll}
\mathrm{HL}^{+}\left(\mathrm{H}_{2} \mathrm{O}\right)+2 \mathrm{H}_{2} \mathrm{O} \leftrightarrow \mathrm{L}\left(\mathrm{H}_{2} \mathrm{O}\right)_{2}+\mathrm{H}_{3} \mathrm{O}^{+} & \mathrm{K}_{\mathrm{a} 2} \\
\mathrm{H}_{2} \mathrm{~L}^{+} 2 \mathrm{H}_{2} \mathrm{O} \leftrightarrow \mathrm{HL}^{-}\left(\mathrm{H}_{2} \mathrm{O}\right)+3 \mathrm{H}_{3} \mathrm{O}^{+} & \mathrm{K}_{\mathrm{b} 2}
\end{array}
$$

The equilibrium constant $\mathrm{K}_{\mathrm{a} 2}$ and $\mathrm{K}_{\mathrm{b} 2}$ that characterizes the above reactions, are as follows:

$$
\begin{aligned}
& \mathrm{K}_{\mathrm{a} 2}=\mathrm{K}_{\mathrm{C} 2} \times \mathrm{K}_{\mathrm{N} 2} \\
& \mathrm{~K}_{\mathrm{b} 2}=\mathrm{K}_{\mathrm{D} 2} \times \mathrm{K}_{\mathrm{N} 3}
\end{aligned}
$$

These equations were used to determine theoretically the value of the second ionization constant of Chlorthalidone and Terbutaline in water. Table 3 and 4 summarize the optimized values of molecular properties of the neutral Chlorthalidone (Figure 5c), and also the $\mathrm{H}_{2} \mathrm{~L}$ zwitterion, $\mathrm{OH}^{-}\left(\mathrm{H}_{2} \mathrm{O}\right)_{3}$ ion, and $\mathrm{HL}^{-}\left(\mathrm{H}_{2} \mathrm{O}\right)$ anion molecule (Figure 6) for Terbutaline obtained at the B3LYP/6-31+G(d) level of theory with Tomasi's method in water at $298.15 \mathrm{~K}$. Evidently, the formation of the neutral Chlorthalidone implies that the electronic density of the N9 atom decreases notably (in absolute value) with respect to the N9 atom of the Chlorthalidone cation $(+1)$, as shown Table 3. Also, the formation of the Terbutaline anion implies that the electronic density of the N10 atom decreases notably (in absolute value) with respect to the $\mathrm{N} 10$ atom of the Terbutaline zwitterion (Table 4).

It can be observed that the $p_{k 2}$ value (Chlorthalidone and Terbutaline) theoretically calculated $\left(p_{k 2}=10.96\right.$ and 9.93$)$ is relatively comparable with the experimentally determined $\mathrm{pKa}\left(\mathrm{pK}_{\mathrm{a} 2}=10.82\right.$ and 9.54) [42].

\section{Third Ionization Constant of Terbutaline}

Also, it is selected that the $\mathrm{HL}^{-}$anion suffers a total neutralization process as follows:

$$
\mathrm{HL}^{-}+\mathrm{OH}^{-}\left(\mathrm{H}_{2} \mathrm{O}\right)_{3} \leftrightarrow \mathrm{L}^{2-}\left(\mathrm{H}_{2} \mathrm{O}\right)+3 \mathrm{H}_{2} \mathrm{O}
$$

In the above reaction, $\mathrm{L}^{-2}$ represents the second anion of Terbutaline. The reaction described in Eq. (25) is characterized by another equilibrium constant, $\mathrm{K}_{\mathrm{C} 3^{\prime}}$ which was also theoretically determined. By combining Equations (12) and (29), the Third ionization reaction of Terbutaline was obtained:

$\mathrm{HL}^{-}+2 \mathrm{H}_{2} \mathrm{O} \leftrightarrow \mathrm{L}^{2-}\left(\mathrm{H}_{2} \mathrm{O}\right)+\mathrm{H}_{3} \mathrm{O}^{+}$

The third ionization constant $\left(\mathrm{K}_{\mathrm{a} 3}\right)$ that characterizes the above reaction is associated with constants $\mathrm{K}_{\mathrm{C} 3}$ and $\mathrm{K}_{\mathrm{N} 3}$ by Equation 31:

$\mathrm{K}_{\mathrm{a} 3}=\mathrm{K}_{\mathrm{c} 3} \times \mathrm{K}_{\mathrm{N} 3}$

The above equation was used to determine theoretically the value of the third ionization constant of Terbutaline in water. Table 4 summarizes the optimized values of molecular properties of the $\mathrm{HL}-$ anion (Figure 7), $\mathrm{OH}^{-}\left(\mathrm{H}_{2} \mathrm{O}\right)_{3}$ ion, and $\mathrm{L}^{2-}\left(\mathrm{H}_{2} \mathrm{O}\right)$ anion molecule (Figure 7 ) obtained at the B3LYP/6$31+G(d)$ level of theory with Tomasi's method in water at $298.15 \mathrm{~K}$. Obviously, the formation of the Terbutaline anion $\left(\mathrm{L}^{2-}\right)$ implies that the electronic density of the 033 atom increases notably (in absolute value) with respect to the 034 atom of the Terbutaline anion ( $\mathrm{HL}$ ) (Table 4).

It can be observed that the $\mathrm{pK}_{\mathrm{b} 2}$ value theoretically calculated $\left(\mathrm{pK}_{\mathrm{b} 3}=10.88\right)$ is relatively comparable with the experimentally determined $\mathrm{p}_{\mathrm{Kb}}$ $\left(\mathrm{pK}_{\mathrm{b} 3}=10.45\right)$ [42].

The molecule of water originated from the acidbase reaction, together with the hydration water molecule of the Chlorthalidone and Terbutaline, and these are the molecules of water that interact with the Chlorthalidone and Terbutaline molecules by means of IHBs. Figure $5 \mathrm{a}$ shows that the distance and bond angle formed by the involved atoms (H35036, 036H35N22) in the IHB are $1.63926 \AA$ and 176.57410, respectively. According to ref 45 and 48 , The IHB of this cation is moderate. Similarly, the IHB of the Chlorthalidone cation (+1), the neutral Chlorthalidone and zwitterion of Terbutaline belongs to the moderate closely to weak. Also, the IHB of the anions of Terbutaline belongs to the moderate closely to strong, as shown in Tables 3 and 4. Finally, it must be noted that IHB data can be use in the design of benefit and economical nanodrugs 
Table 4. Calculated Structural Magnitudes Using Tomasi's method at the B3LYP/6-31+G(d) Level of Theory for the Cations, Neutral Molecule of Terbutaline at $298.15 \mathrm{~K}$.

\begin{tabular}{|c|c|c|c|c|c|c|}
\hline \multirow{2}{*}{$\begin{array}{c}\text { Species } \\
\text { Terbutaline }\end{array}$} & \multicolumn{6}{|c|}{ Calculated Magnitudes } \\
\hline & $\mathrm{H}_{3} \mathrm{~L}^{+}$ & $\mathrm{H}_{2} \mathrm{~L}\left(\mathrm{H}_{2} \mathrm{O}\right)$ & $\mathrm{H}_{2} \mathrm{~L}$ & $\mathrm{HL}^{-}\left(\mathrm{H}_{2} \mathrm{O}\right)$ & HL- & $L^{-2}\left(H_{2} O\right)$ \\
\hline$K_{D 1}$ & $1.10203 \times 10+28$ & - & - & - & - & - \\
\hline $\mathrm{K}_{\mathrm{D} 2}$ & - & - & $1.31883 \times 10+29$ & - & - & - \\
\hline $\mathrm{K}_{\mathrm{D} 3}$ & - & - & - & - & $1.18412 \times 10+30$ & - \\
\hline $\mathrm{K}_{\mathrm{b} 1}$ & 706940668 & - & - & - & - & - \\
\hline $\mathrm{K}_{\mathrm{b} 2}$ & 8460184083 & - & - & - & - & - \\
\hline $\mathrm{K}_{\mathrm{b} 3}$ & 75960017400 & - & - & - & - & - \\
\hline$a_{0}$ & 4.83 & 5.24 & 5.21 & 5.25 & 4.94 & 5.08 \\
\hline $\mathrm{A036H3708}$ & - & 140.01703 & - & - & - & - \\
\hline AN1OH23O36 & - & 141.8248 & - & - & - & - \\
\hline А035Н37034 & - & - & - & 171.22513 & - & - \\
\hline А034H36015 & - & - & - & - & - & 178.26984 \\
\hline dO8H37 & - & 1.903 & - & - & - & - \\
\hline $\mathrm{dO} 36 \mathrm{H} 23$ & - & 1.91285 & - & - & - & - \\
\hline dO34H37 & - & - & - & 1.69809 & - & - \\
\hline d015H36 & - & - & - & - & - & 1.60425 \\
\hline qN10 & -0.728662 & -0.786153 & -0.73998 & -0.398989 & -0.46447 & -0.467017 \\
\hline q08 & -0.773568 & -0.834024 & -0.72149 & -0.752051 & -0.80841 & -0.813892 \\
\hline q015 & -0.780143 & -0.795078 & -0.79112 & -0.791939 & -0.796125 & -1.014998 \\
\hline q033 & - & - & - & - & - & -0.980297 \\
\hline q034 & - & - & - & -0.959339 & -0.93215 & -1.125891 \\
\hline q035 & - & -0.920977 & -0.92307 & -1.114995 & - & - \\
\hline \multirow[t]{2}{*}{ q036 } & - & -1.12687 & - & - & - & - \\
\hline & -0.789211 & - & - & - & - & - \\
\hline$D-C 4 C 2 C 1 C 3$ & 0.43675 & 0.715758 & 0.524039 & 0.428692 & 0.728914 & 1.227871 \\
\hline$D-C 5 C 3 C 1 C 2$ & -0.343587 & -0.480222 & -0.3195 & -0.273286 & -0.440616 & -0.993797 \\
\hline$D-C 6 C 5 C 3 C 1$ & -0.114031 & -0.107579 & -0.20194 & -0.340209 & - & - \\
\hline$D-C 6 C 4 C 2 C 1$ & - & - & - & - & -0.326334 & -0.76845 \\
\hline$D-C 7 C 3 C 1 C 2$ & 178.755146 & -179.6147 & -179.74 & -179.8691 & -179.9317 & -179.45804 \\
\hline$D-08 C 7 C 3 C 1$ & 137.429313 & 124.83565 & 123.741 & 124.27799 & 124.8866 & 126.488056 \\
\hline D-C9C7C 3 C 1 & -105.749265 & -115.5787 & -117.795 & -111.994 & -113.4004 & -112.55841 \\
\hline D-N10C9C7C3 & -171.570301 & -163.7614 & -163.32 & 168.75447 & -173.2636 & -172.09556 \\
\hline D-C11N10C9C7 & 166.91148 & -171.3762 & 161.0855 & 179.58776 & -93.94761 & -94.268028 \\
\hline D-C12C11N10C9 & 176.524133 & -172.7705 & 175.966 & 176.76981 & 171.9442 & 171.220353 \\
\hline D-C13C11N10C9 & -64.652973 & -53.34922 & -65.1655 & -65.84131 & -71.05039 & -71.889549 \\
\hline D-C14C11N10C9 & 57.327208 & 68.472449 & 56.61855 & 56.922857 & 51.71159 & 50.87956 \\
\hline D-015C2C1C3 & -179.921752 & -179.7674 & -179.844 & 179.87817 & -179.9048 & -179.55796 \\
\hline
\end{tabular}


26 | F. Kiani and A. Rajabalinezhad / Hacettepe J. Biol. \& Chem., 2018, 46 (1), 13-29

Table 4. Calculated Structural Magnitudes Using Tomasi's method at the B3LYP/6-31+G(d) Level of Theory for the Cations, Neutral Molecule of Terbutaline at $298.15 \mathrm{~K}$ (continue).

\begin{tabular}{|c|c|c|c|c|c|c|}
\hline D-H16C1C3C5 & 178.858907 & 178.17527 & 178.0466 & -178.4323 & - & 177.061977 \\
\hline D-H16C1C2C 4 & - & - & - & - & -177.8487 & - \\
\hline D-H17C4C2C1 & 179.497525 & 179.99705 & -179.964 & 179.7405 & 179.8799 & 179.656523 \\
\hline D-H18C5C3C1 & -178.65648 & 178.33117 & 178.7774 & 178.57563 & 177.7021 & 175.267853 \\
\hline D-H19C7C3C1 & 14.716872 & 5.790718 & 4.028713 & 6.779443 & 8.227176 & 9.719289 \\
\hline D-H2008C7C3 & -48.881118 & -0.535404 & 3.566009 & 3.791477 & 10.40072 & 9.379499 \\
\hline D-H21C9C7C3 & -54.130222 & -45.23875 & -46.2391 & -71.26685 & -52.49135 & -51.589765 \\
\hline $\mathrm{D}-\mathrm{H} 22 \mathrm{C} 9 \mathrm{C} 7 \mathrm{C} 3$ & 68.106797 & 76.037769 & 76.18596 & 44.472684 & 62.64193 & 63.73312 \\
\hline D-H23N10C9C7 & -68.955213 & -44.02643 & -73.3176 & -55.81476 & 33.70633 & 31.454611 \\
\hline D-H24N10C9C7 & 43.420651 & 65.345162 & 38.22395 & - & - & - \\
\hline D-H24C12C11N10 & - & - & - & 178.67598 & 176.7455 & 176.886624 \\
\hline D-H25C12C11N10 & 179.358828 & 65.345162 & 179.3902 & -61.66615 & -63.52368 & -63.3316 \\
\hline D-H26C12C11N10 & -61.875869 & -58.68381 & -61.6162 & 57.897276 & 56.17431 & 56.176564 \\
\hline D-H27C12C11N10 & 60.478921 & 62.624266 & 60.22582 & - & - & - \\
\hline D-H27C13C11N10 & - & - & - & -172.7262 & -176.2895 & -176.28462 \\
\hline D-H28C13C11N10 & -174.13763 & -174.4564 & -174.796 & -52.56811 & -55.90301 & -55.763377 \\
\hline D-H29C13C11N10 & -55.723089 & -55.75045 & -56.0816 & 67.594404 & 63.92951 & 63.832794 \\
\hline D-H3OC13C11N10 & 67.326907 & 66.400544 & 66.23309 & - & - & - \\
\hline D-H30C14C11N10 & - & - & - & 177.35701 & 177.467 & 178.05327 \\
\hline D-H31C14C11N10 & 174.905789 & 175.60185 & 175.9323 & -62.58781 & -62.79616 & -61.839087 \\
\hline D-H32C14C11N10 & -66.353409 & -65.43026 & -65.0011 & 57.508329 & 57.41653 & 57.853294 \\
\hline D-H33C14C11N10 & 56.456058 & 56.886217 & 57.14056 & - & - & - \\
\hline D-H33015C2C1 & - & - & - & -178.655 & -178.8565 & - \\
\hline D-H34015C2C1 & -178.511186 & -178.8125 & -178.569 & - & - & - \\
\hline D-035C6C5C 3 & -179.662513 & 179.65356 & 179.6185 & - & - & - \\
\hline D-H36035C6C5 & 178.908676 & - & - & - & - & - \\
\hline D-03608C7C3 & - & -158.8168 & - & - & - & - \\
\hline D-H3703608C7 & - & 129.12879 & - & - & - & - \\
\hline D-H3803608C7 & - & 89.603925 & - & - & - & - \\
\hline D-034C6C4C2 & - & - & - & -179.6065 & -179.8231 & - \\
\hline D-035034C6C4 & - & - & - & 170.67133 & - & - \\
\hline D-H36035034C6 & - & - & - & -103.5901 & - & - \\
\hline D-H37035034C6 & - & - & - & 64.627751 & - & - \\
\hline D-033C6C4C2 & - & - & - & - & - & -179.21227 \\
\hline D-034015C2C1 & - & - & - & - & - & -179.51738 \\
\hline D-H35034015C2 & - & - & - & - & - & 0.580446 \\
\hline D-H36034015C2 & - & - & - & - & - & -171.85203 \\
\hline
\end{tabular}

${ }^{\mathrm{a}} \mathrm{K}_{\mathrm{D} 1}, \mathrm{~K}_{\mathrm{D} 2}$ and $\mathrm{K}_{\mathrm{D} 3^{\prime}}$ equilibrium constants of equations; $\mathrm{K}_{\mathrm{b} 1}, \mathrm{~K}_{\mathrm{b} 2}$ and $\mathrm{K}_{\mathrm{b} 3^{\prime}}$ acidic dissociation constants of species in water; $\mathrm{D}$, dihedral angle between the indicated atoms $(\AA)$; a , Bohr radius $(\AA) ; q$, total atomic charge (Muliken) (au); r, bond lengths between the indicated atoms; $d$, distance of the IHB between the indicated atoms $(\AA) ; A, H$-bond angles $\left(^{\circ}\right)$. 

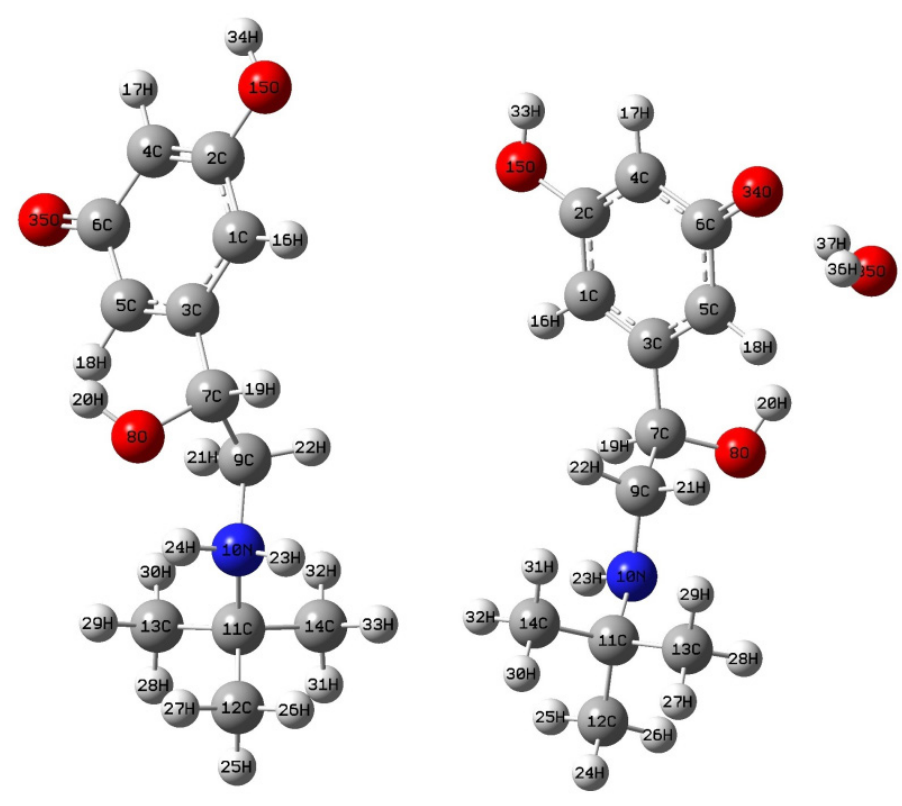

Figure 6. Calculated structure for (a) the Terbutaline anion $\left(\mathrm{H}_{2} \mathrm{~L}\right)$ and (b) the Terbutaline zwitterion $\left(\mathrm{HL}^{-}\left(\mathrm{H}_{2} \mathrm{O}\right)\right)$, at the B3LYP/6-31+G(d) level of theory and using Tomasi's method in water at $298.15 \mathrm{~K}$.
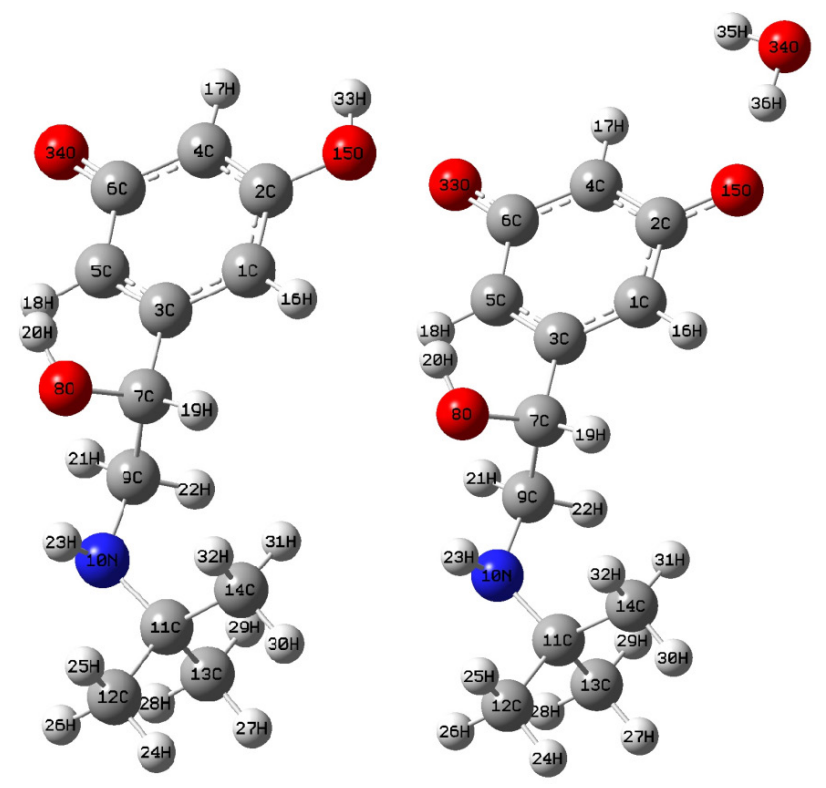

Figure 7. Calculated structure for the Terbutaline anions, at the B3LYP/6-31+G(d) level of theory and using Tomasi's method in water at $298.15 \mathrm{~K}$.

that are very useful in the treatment of disease.

\section{CONCLUSIONS}

In this study, we showed the possibility of a theoretical method that uses $\mathrm{pH}$ values to determine the ionization constants of Chlorthalidone and Terbutaline. Also, the autoprotolysis constants calculated with an acceptable degree of accuracy. With this purpose, we selected various acid-base reactions that take into account the solvation of the hydrogen, hydroxyl ions, and other cations or anions in protic solvents such as water, which possess a high hydrogen-bond-donor capability. The calculations performed at the B3LYP/6-31+G(d) levels of theory using Tomasi's method allowed us to prove that cations, neutral molecules, and anions form IHBs with some molecules of water. The autoprotolysis constants theoretically show a suitable agreement with the autoprotolysis constants experimentally determined by the CE 
method.

\section{ACKNOWLEDGMENT}

Thanks are gratefully extended to the Faculty of Chemistry, Semnan University and Islamic Azad University, Ayatollah Amoli Branch for their valuable helps with this work.

\section{References}

1. D.G. Arkfield, E. Rubenstein, Quest for the Holy Grail to cure arthrithis and osteoporosis: emphasis on bone drug delivery systems, Adv. Drug. Deliver. Rev., 57 (2005) 939-944.

2. M.O. Emeje, I.C. Obidike, E.I. Akpabio, S.I. Ofoefule, Toxicology and pharmaceutical science, Recent Advances in Novel Drug Carrier Systems, InTech, Turkey, 2012.

3. R.W. Matthew, R. Agarwal, Heart disease and stroke statistics, Am. Heart Assoc., 59 (2012) 1089-1095.

4. D.H. Ellison, J. Loffing, Thiazide effects and side effects: insights from molecular genetics, Am. Heart Assoc., 54 (2009) 196-202.

5. Sica DA, Resistant hypertension: diagnosis, evaluation, and treatment, Am. Heart Assoc., 47 (2006) 321-322.

6. Kurtz TW, Chlorthalidone: don't call it "thiazide-like" anymore, Am. Heart Assoc., 56 (2010) 335-337.

7. E.K. Main, D.M. Main, S.G. Gabbe, Chronic oral terbutaline tocolytic therapy as associated with maternal glucose intolerance, Am. J. Obstetrics \& Gynecolog., 157 (1987) 644-647.

8. J.E. Gerich, M. Langlois, C. Noacco, V. Schneider P.H. Forsham, Adrenergic modulation of pancreatic glucagon secretion in man, J. Clinical. Inves., 53 (1974) 1441-1446.

9. L.P. Boulet, A. Becker, D. Bérubé, (CAMJ) Can. Med Assoc. J., 161 (1999) S1-S62.

10. Z. Jia, T. Ramstad, M. Zhong, Medium-throughput pK a screening of pharmaceuticals by pressure-assisted capillary, Electrophoresis., 22 (2001) 1112-118.

11. C.E. Kibbey, S.K. Poole, B. Robinson, J.D. Jackson, D. Durham, An integrated process for measuring the physicochemical properties of drug candidates in a preclinical discovery environment, J. Pharm. Sci., 90 (2001) 1164-1175

12. W. Stumm, J.J. Morgan, Aquatic chemistry: chemical equilibria and rates in natural waters, Wiley Interscience, New York (1996).

13. G. Thomas, Medicinal chemistry, an introduction, John Wiley \& Sons: West Sussex (2000).

14. A. Avdeef, J.J. Bucher, Accurate measurements of the concentration of hydrogen ions, Anal. Chem., 50 (1978) 2137-2142.

15. Z. Qiang, C. Adams, Potentiometric determination of acid dissociation constants ( $\mathrm{pKa}$ ) for human and veterinary antibiotics, Water. Res., 38 (2004) 2874 2890.

16. J.L. Beltra'n, N. Sanli, G. Fonrodona, D. Barro'n, G. Ozkanb, J. Barbosa, Spectrophotometric potentiometric and chromatographic pKa values of polyphenolic acids in water and acetonitrile-water media, Anal. Chim. Acta., 484 (2003) 253-263.

17. H.Y. Ando, T. Heimbach, pKa determinations by using a HPLC equipped with DAD as a flow injection apparatus, J. Pharm \& Biomedical. Anal., 16 (1997) 31-
39.

18. S.K. Pool, S. Patel, K. Dehring, H. Workman, C.F. Pool, Determination of acid dissociation constants by capillary electrophoresis, J. Chromatography, A. 1037 (2004) 445-454.

19. P. Janoš, Determination of equilibrium constants from chromatographic and electrophoretic measurements, J. Chromatography. A., 1037 (2004) 15-28.

20. C.P. Kelly, C.J. Cramer, D.G. Truhlar, Adding explicit solvent molecules to continuum solvent calculations for the calculation of aqueous acid dissociation constants, J. Phys. Chem, A., 110 (2006) 2493-2499.

21. K. Mohle, H.J. Hofmann, Stability order of basic peptide conformations reflected by density functional theory, J. Mol. Model., 4 (1998) 53-60.

22. R.D. Tosso, M.A. Zamora, F.D. Survire, R.D. Enriz, Ab initio and DFT study of the conformational energy hypersurface of cyclic Gly-Gly-Gly, J. Phys. Chem. A. 113 (2009) 10818-10825.

23. P. Hudaky, A. Perczel, Conformation dependence of pKa: $A b$ initio and DFT investigation of histidine, J. Phys. Chem. A., 108 (2004) 6195-6205.

24. M.D. Liptak, K.C. Gross, P.G. Seybold, S. Feldgus, G.C. Shields, Absolute pKa determinations for substituted phenols, J. Am. Chem. Soc., 124 (2002) 6421-6427.

25. N.S. Sosnowska, Calculation of acidic dissociation constants in water: solvation free energy terms. Their accuracy and impact, Theor. Chem. Account., 118 (2007) 281-289.

26. P. Hohenberg, W. Kohn, Inhomogeneous electron gas, Phys. Rev. B., 136 (1964) 864-871.

27. A.D. Becke, Density-functional exchange-energy approximation with correct asymptotic behavior, Phys. Rev, A., 38 (1988) 3098-4003.

28. C. Lee, W. Yang, R.G. Parr, Development of the ColleSalvetti correlation-energy formula into a functional of the electron density, Phys. Rev, B., 37 (1988) 785 792.

29. B.G. Johnson, M.J. Frisch, Analytic second derivatives of the gradient-corrected density functional energy. Effect of quadrature weight derivatives, Chem. phys. Lett., 216 (1993) 133-139.

30. W.J. Hehre, L. Radom, P.V.R. Schleyer, A.J. Pople, $A b$ initio molecular orbital theory, Wiley, New York (1989).

31. Z. Dega-Szafran, A. Katrusiak, M. Szafran, Molecular structure of the complex of $\mathrm{N}$-methylmorpholine betaine with 2,4-dinitrophenol, J. Mol. Struct., 741 (2005) 1-9.

32. Program CS Chem3D 5.0; Program for Molecular Modeling and Analysis; Cambridge Soft Corporation: MA, USA (2000).

33. M.J. Frisch et al. Gaussian 98, revision A.6; Gaussian, Inc.: Pittsburgh, PA (1998).

34. Miertus S, Tomasi EJ, Approximate evaluations of the electrostatic free energy and internal energy changes in solution processes, Chem phys 1982;65: 239-245.

35. H.A. Laitinen, W.E. Harris, Chemical Analysis McGraw-Hill: New York (1975).

36. R.I. Allen, K.J. Box, J.E.A. Comer, C. Peake, K.Y. Tam, Multiwavelength spectrophotometric determination of acid dissociation constants of ionizable drugs, J. 
Pharm \& Biomedical. Anal., 17 (1998) 699-712.

37. K. Taka'cs-Nova'k, B. Nosza'l, M. To“ke's-Ko“vesdi, G. Sza'sz, Acid-base properties of terbutaline in terms of protonation macro- and microconstants, J. Pharm \& Pharmacology., 47 (1995) 431-438.

38. Z. Szakacs, M. Krasni, B. Noszal, Determination of microscopic acid-base parameters from NMR-pH titrations, Anal \& Bioanal. Chem., 378 (2004) 14281448.

39. M. Borkovec, M. Brxnda, G.J.M. Koper, B. Spiess, Resolution of microscopic Protonation mechanisms in polyprotic molecules, Int. J. Chem., 56 (2002) 695700.

40. D.L. Rabenstein, T.L. Sayer, Determination of microscopic acid by nuclear magnetic resonance spectrometry, J. Anal. Chem., 48 (1976) 1141-1146.

41. M. Shalaeva, J. Kenseth, F. Lombardo, A. Bastin, Measurement of dissociation constants ( $p$ Ka values) of organic compounds by multiplexed capillary electrophoresis using aqueous and cosolvent buffers,
J. Pharm. Sci., 97 (2008) 2581-2606.

42. P.W. Atkins, Physical Chemistry, 6th ed., Oxford University Press, England (1998).

43. F. Ruff, I.C. Csizmadia, Organic reactions, equilibria, kinetics and mechanism, Elsevier, London (1994).

44. G.A. Jeffrey, An introduction to hydrogen bonding, Oxford University Press, Oxford (1997).

45. S.E. Blanco, M.C. Almandoz, F.H. Ferretti, Determination of the overlapping $\mathrm{pKa}$ values of resorcinol using UV-visible spectroscopy and DFT methods, Spectrochimica. Acta. Part A., 61 (2005) 93-102.

46. Y. Marcus, The properties of organic liquids that are relevant to their use as solvating solvents, Chem. Soc. Rev., 22 (1993) 409-416.

47. F. Kiani, A.A. Rostami, S. Sharifi, A. Bahadori, M.J. Chaichi, Determination of acidic dissociation constants of glycine, valine, phenylalanine, glycylvaline, and glycylphenylalanine in water using ab initio methods, J. Chem \& Eng. Data., 55 (2010) 2732-2740. 
